\title{
The impact on nutrient cycles from tropical forest to pasture conversion in Costa Rica
}

\author{
Kelly Bringhurst ${ }^{1,2} \cdot$ P. Jordan ${ }^{1}$
}

Received: 26 January 2015/Accepted: 26 March 2015/Published online: 9 April 2015

(C) Springer International Publishing 2015

\begin{abstract}
Changes in nutrient and hydrological cycles caused by land disturbance typically lead to detrimental changes to ecosystems. This study utilized a paired, smallcatchment approach to examine the effect of deforestation on soils and streams of the tropical Osa Peninsula, Costa Rica. The first catchment had been cleared for pasture and the second consisted of undisturbed tropical wet forest. Soil concentrations of organic matter, total and soil-available phosphorus $(\mathrm{P})$ were higher in the forested catchment with reductions of $>33 \%$ of each in the deforested catchment. The effect of deforestation on stream discharge was a $59 \%$ increase in flow during the wet season and a higher Q5:Q95 (percentile flow) ratio showing that the deforested stream yielded shorter duration, higher magnitude flood peaks. The deforested catchment loss of dissolved inorganic nitrogen increased $95 \%$ over the forested catchment. Soluble reactive phosphorus showed a $43 \%$ higher load in the deforested catchment compared to the forested catchment. The molar N:P ratios were low and both streams were well below the level at which $\mathrm{N}$ limitation of lotic algal growth has been reported. It, therefore, appears that $\mathrm{N}$ is the limiting nutrient in streams in the study area. Soil nutrient depletion in the deforested catchment, accelerated by a changed hydrological regime, is the likely trajectory of soil-water interactions in this tropical ecosystem. Loss of nutrients and organic matter from terrestrial ecosystems will likely lead to long-term impacts on lowland tropical
\end{abstract}

Kelly Bringhurst

kbringhurst@dixie.edu

1 School of Environmental Sciences, University of Ulster, Coleraine, Northern Ireland, UK

2 Dixie State University, 225 South 700 East, St. George, UT 84770, USA communities. Should deforestation become widespread along this stretch of the Pacific coastline possible eutrophication of receiving transitional and coastal waters may occur.

Keywords Eutrophication - Phosphorus - Nitrogen · Deforestation - Tropical wet forest

\section{Introduction}

Deforestation is an environmental issue of global concern that causes changes to ecosystems, species populations, hydrological regimes, nutrient dynamics and carbon sequestration (Williams 2008). However, such changes are not well characterized throughout the tropics, and may carry significant consequences for ecological functions and service. Previous studies throughout the tropics have shown considerable impacts of deforestation on stream nutrient patterns (Borbor-Cordova et al. 2006; YanezArancibia and Lara-Dominquez 1998; Werner 1984; Jordan and Herrera 1981). In particular, deforestation may increase nitrogen $(\mathrm{N})$ and phosphorus $(\mathrm{P})$ loads to downstream aquatic communities and potentially drive eutrophication. This may be especially true in coastal terrestrial ecosystems, where the deforestation impacts could quickly transmit through streams to coastal margins and the ocean. Cleared land can also have a profound impact on the microbial communities in soils and have a potentially serious effect on nutrient transformation (Cleveland et al. 2004). In this study, it was hypothesized that deforestation would change the long-term source characteristics of nutrients in the soil and the transport characteristics in the streams. Changes will likely lead to greater hydrological discharge, N, P and sediment loads in 
streams and adding stress to freshwater and marine ecosystems. Nitrogen and $\mathrm{P}$ are of greatest concern as the impacts of eutrophication can typically contribute to deterioration of water quality, changes to aquatic biota and eventually to hypoxia in receiving water bodies (Downing et al. 1999; Biggs et al. 2004).

Costa Rica is known for its conservation policies, yet $70 \%$ of remaining forests are located outside of protected areas. The Mesoamerican biological corridor project seeks to connect protected areas to allow species room to migrate and adapt, yet economic development has already caused the loss of important linkages between protected lands (Sanchez-Azofeifa et al. 2003). Costa Rica faces difficult choices as both immediate and future development will likely cause increased isolation of protected areas (Spring and Baum 2010).

The Osa Peninsula in Costa Rica was chosen for this study because it has been a largely unspoiled tropical wet ecosystem that faces mounting pressure for the development. Very few studies have been done in the area, none of which address nutrient transfer in streams. Deforestation for agricultural use requires continual clearing of pioneering species and is likely to lead to long-term changes to land-use and nutrient' transfer. The objective of this research was to quantify the effects of tropical deforestation on nutrients' transport from catchments. Correlation between land-use and nutrient flux was determined in the streams by collecting hydrological and hydrochemical data on the streams under different flow conditions. Chemical composition of water leaving a catchment represents an integration of biotic and abiotic processes that occur along flow paths within the catchment and is a result of hydrological and biogeochemical coupling (Lohse et al. 2009). Since no prior studies have been published on the effect of land use on nutrient transfers on the Osa Peninsula of Costa Rica, this study sought to correlate stream discharge to nutrient transfer to assess the significance of future development in the area on nutrient transfers.

\section{Materials and methods}

\section{Study site}

The study area is located on the Osa Peninsula of Costa Rica (lat. $8^{\circ} 38^{\prime} \mathrm{N}$, long. $83^{\circ} 43^{\prime} \mathrm{W}$ ) in a humid tropical climate. Temperatures average approximately $26{ }^{\circ} \mathrm{C}$ year round, while humidity ranges from 60 to $100 \%$. Rainfall is dominated by the Pacific rainfall regime and can be intense and is seasonably variable. Annual rainfall averages over $5,000 \mathrm{~mm} \mathrm{year}^{-1}$ with a dry season typically from December through April (Cleveland and Townsend 2006). The study focused on two small catchments of similar size

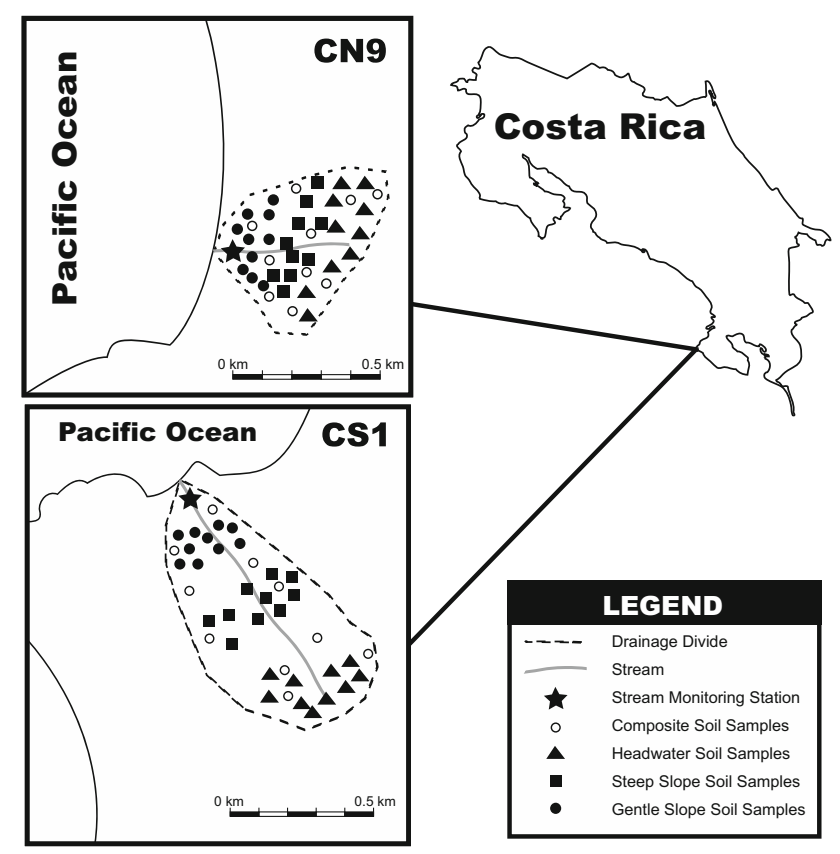

Fig. 1 Study sites on the Osa Peninsula, Costa Rica showing drainage divides (dashed lines) and the locations of soil sampling and hydrological monitoring. CN9 is the deforested catchment and CS1 the forested catchment

and order $\left(<0.4 \mathrm{~km}^{2}\right)$ located $2 \mathrm{~km}$ apart (Fig. 1). The forested catchment (CS1) is part of one of the last remaining stands of evergreen tropical wet forests on the Pacific Coast of the Mesoamerican Isthmus (Hartshorn 1983; Sanchez-Azofeifa et al. 2002). The second catchment (CN9) has been cleared for pasture with continued clearing of secondary growth through December 2008. A large portion of this catchment is dominated by the introduced grass Panicum maximum. Land use in the study area is mostly limited to small farms; otherwise the land is left to its natural forested state. Future road building for tourism infrastructure will likely see more deforestation leading to the loss of connectivity of protected areas. Soils in both catchments have been classified as an ultisol that formed from both basalt and marine sedimentary rocks (Bern et al. 2005). Uplift of the area has caused the older soils to be exposed on ridges and steep slopes, leading to rapid erosion of the older soils. Uplift rates for the Osa Peninsula are between 2 and $6.5 \mathrm{~mm}$ per year, with recent rates toward the upper end (Gardner et al. 1992).

\section{Field and laboratory methods}

Methods were chosen that included direct measurement of $\mathrm{P}$ and $\mathrm{N}$ in soils (as the primary nutrient source interacting with the hydrological transport component) and transfers in river water. Transfer of nutrients in river water was monitored with a number of grab, passive and storm techniques. 
Other parameters (such as soil $\mathrm{pH}$, soil organic matter, suspended sediment nutrient levels and turbidity) that may impact nutrient transfer were measured and used as supporting data.

Composite soil samples were collected in December 2008 (start of dry season) for each catchment by removing the surface layer of vegetation and leaf litter and collecting from the surface down to approximately $0.1 \mathrm{~m}$ depth at 10 locations. Additional stratified random soil samples were collected in June 2009 (beginning of wet season) from each of three slope categories-headwater $(<5 \%)$, steep $(>30 \%)$ and gentle $(<10 \%)$. To obtain data on the nutrient concentration of suspended sediments eroded from terrestrial soils, time-integrated suspended sediment samplers were constructed using a design described by Phillips et al. (2000) and deployed in each catchment stream for the duration of the study period. Soil and sediment samples were air-dried in plastic trays and subsequently sifted using a \#10 (0.002 m mesh) U.S. Standard Testing Sieve and stored in plastic bags for analysis (Pierzynski 2000). Samples were sent from San Jose, Costa Rica, to the Stukenholtz Laboratory in Twin Falls, Idaho, for analysis of P (total and soil available of Bray and Kurtz (1945)), N (as $\mathrm{NH}_{4}{ }^{+}$and $\mathrm{NO}_{3}{ }^{-}$, using the method of Keeney and Nelson (1982)), organic matter (using the loss on ignition method of Storer (1984)) and pH.

Rainfall was collected using two manual rain gauges deployed in an open grassy area; data were recorded at 06:00 and 18:00 h each day. There was no local official meteorological station and twice-daily data were the only source of rainfall information in the area.

First-order streams drained the two catchments and the cleared pasture had no other anthropogenic influences such as artificial fertilization. Locations for water stage readings were chosen in small pools with riffles both upstream and downstream of the pool (Carter and Davidian 1989). Such locations will respond quickly to discharge changes and be less susceptible to erosion. Water stage (water surface level) was recorded every 15 min using a LevelTROLL 100 non-vented absolute pressure sensor relative to the stream bed. Water depth was determined by taking pressure readings that were converted to depth using the density of fresh water. A BaroTROLL was deployed at the field station and recorded barometric pressure every $15 \mathrm{~min}$ to reference the unvented LevelTROLL readings. Approximately once a month, the data were downloaded from the TROLL devices deployed in the streams to a laptop computer. Corrected data gave water stage $(0.000 \mathrm{~m})$ at 15 -min intervals with an accuracy of $\pm 0.2 \%$.

The stage-discharge method was used to obtain a continuous discharge measurement from the stage data (Harmel et al. 2006). Stage-discharge relationships were established (using least-square regression) by correlating a range of stage measurements with discharge $\left(\mathrm{m}^{3} \mathrm{~s}^{-1}\right)$ measured using the velocity-area method (divided into cells). This process was repeated for the entire range of expected discharges that could safely be measured (Harmel et al. 2006). Safety concerns limited discharge measurements to daytime rains because of dangers in traveling to the streams at night due to potential flood hazards and venomous snakes.

Methods used to determine nutrient concentrations across ranges of flows in each study catchment were complicated due to the remote location, lack of infrastructure (including electricity and roads) and costs that prevented the use of automated stream sampler and analysis equipment. Passive sampler technology (Sorbicell cartridges) was used to determine flow-proportional nutrient flux over deployment periods of days and weeks (De Jonge and Rothenberg 2005). While the Sorbicell cartridge is new technology, recent studies in the Netherlands showed that the average solute concentration measurements obtained using Sorbicell cartridges produce more consistent load estimates than concentrations determined from conventional grab samples (Rozemeijer et al. 2010). While at times the Sorbicell cartridges showed lower concentrations than the continuous measurement method, both methods captured the same seasonal concentration patterns of solute transfer.

Sorbicell cartridges were primed with stream water and then mounted in the stream so that they were subjected to stream velocities of $>0.3 \mathrm{~m} \mathrm{~s}^{-1}$. The cells consisted of a porous frit, inside a nylon casing, with $2 \mu \mathrm{m}$ filtration properties at the entrance that regulated the flow rate based upon the hydraulic conductivity of the frit. Cartridges used had hydraulic conductivity ( $K$ values) of $3.1,15$ and 49 . It was found that the $K$ values of 3.1 could be deployed for up to 6 weeks while $K$ values of 49 could be deployed for periods of about 2 weeks, depending upon flow rates in the streams. The intermediate $K=15$ cartridges were found to work best in most conditions. Once water entered the cartridge, an adsorbent attenuated the $\mathrm{P}$ and $\mathrm{N}$ and dissolved a soluble tracer salt (calcium citrate) with known mass and solubility. After the deployment period, the cartridges were collected and sent to Sorbisense laboratories in Denmark for analysis. The difference in mass (m) of the soluble salt gave the volume $(\mathrm{V})$ of water that had moved through the cell (Eq. 1)

$\mathrm{V}=\left(\mathrm{m}_{\mathrm{i}}-\mathrm{m}_{\mathrm{f}}\right) \times \mathrm{K}^{-1}$.

Analysis of the adsorbent gave the total amount of reactive $\mathrm{P}\left(\right.$ as $\left.\mathrm{PO}_{4}-\mathrm{P}\right)$ and $\mathrm{N}$ (as $\mathrm{NO}_{3}{ }^{-} \mathrm{N}$ ) adsorbed. Dividing mass by volume then gave the average concentration of the nutrient that was proportional to the flow of water through the cell over the sampling period. Nutrient concentrations were also determined in grab samples and stormwater samples of stream waters. Grab samples were typically taken each day (typically during a two week span each month from May 2008 to May 2009) in a triple-rinsed 
$250 \mathrm{ml}$ Nalgene bottle, while stormwater samples were collected using the Nalgene stormwater sampler and mounting kit. Grab and storm samples were then brought back to the field station for analysis for $\mathrm{NO}_{3}{ }^{-} \mathrm{N}, \mathrm{NH}_{4}{ }^{+}-\mathrm{N}$, $\mathrm{SRP}, \mathrm{pH}$, electrical conductivity and turbidity. Turbidity measurements were taken using a LaMotte 2020e Turbidimeter and are reported as Nephelometric Turbidity Units (NTU). Soluble P and N concentrations were determined by filtering water samples using a $0.45-\mu \mathrm{m}$ polyvinylidene fluoride syringe filter and analyzed using a Hach DR890 portable colorimeter (detection limit $0.01 \mathrm{mg}$ $\mathrm{L}^{-1}$ ). A portable Hanna Instruments meter was used to measure $\mathrm{pH}$ and electrical conductivity.

In the absence of a digital elevation model, high points on the drainage basin perimeters were recorded using waypoints on a handheld Garmin GPS. The waypoints were imported into GoogleEarthPro and for visualization and calculation of distances and areas. The size of the forested catchment drainage area was approximately $0.4 \mathrm{~km}^{2}(40$ hectares) with a perimeter of $2.5 \mathrm{~km}$ and a length of $1.0 \mathrm{~km}$. This catchment is dominantly primary forest with small patches of secondary forest on the southern edge of the basin. The size of the deforested catchment drainage area was approximately $0.2 \mathrm{~km}^{2}$ (20 hectares) with a perimeter of $1.4 \mathrm{~km}$ and a length of $0.5 \mathrm{~km}$. The majority of this catchment was cleared pasture with small amounts of secondary forest in the upper portion of the basin.

\section{Results and discussion}

\section{Soil samples}

Total soil $\mathrm{P}$ in both catchments ranged between 180 and $560 \mathrm{mg} \mathrm{kg}^{-1}$ while soil-available P for the same samples ranged between 1 and $6 \mathrm{mg} \mathrm{kg}^{-1}$ (Table 1). Total and available $\mathrm{P}$ was relatively abundant in the study area compared to tropical soils that are normally depleted by leaching in stable tectonic regions (Bern et al. 2005). Concentrations for both total and soil-available $\mathrm{P}$ were, however, lower in the deforested catchment for all samples except those taken from the gentle slopes. Greater surface flow on the upper portions of the deforested catchment likely intensified the rate of downslope transfer and led to the $35 \%$ reduction in total $\mathrm{P}$ and the 50-75\% reduction in soil-available $\mathrm{P}$ in the deforested catchment soils. Higher total and soil-available $\mathrm{P}$ in some soils may be due to differences in microbial activity, less surface flow and higher infiltration rates (leading to adsorption of $\mathrm{P}$ onto clays), precipitation of aluminum phosphate, deposition of organic $\mathrm{P}$ and a reduction in leaching rates. Similar results were found in nearby studies on oxisols where microbial biomass was consistently higher in forested sites and resinextractable inorganic $\mathrm{P}$ was less than half as abundant in pasture soils compared to soils in forested areas (Cleveland et al. 2003).

Suspended sediments had similar total $\mathrm{P}$ and soilavailable $P$ concentrations (approximately 400 and $3 \mathrm{mg} \mathrm{kg}^{-1}$, respectively) in the two streams, but which were slightly higher in the deforested catchment probably due to adsorption of $\mathrm{P}$ by the finer fraction of stream sediments sorted via overland flow (Arnscheidt et al. 2007; Caiado 2005).

Soil $\mathrm{pH}$ was slightly acidic and ranged from 4.6 to 5.8 (Table 1), which is common for oxisols and ultisols in the tropics. Suspended sediment collected with the streammounted sampler had the highest $\mathrm{pH}$ values (5.8), possibly increased from lower terrestrial soil $\mathrm{pH}$ values due to continuous contact with stream water with a $\mathrm{pH}$ value of 7.5 .

Soil organic matter, as measured by percent mass loss on ignition (LOI), was higher in the forested catchment as

Table 1 Results of soil sample analysis, composite samples were collected in December 2008 and the remainder of the samples were collected in June 2009

\begin{tabular}{|c|c|c|c|c|c|}
\hline & Composite soil & Headwater soil & Steep slope soil & Gentle slope soil & Suspended sediment \\
\hline CS1 Total $\mathrm{P} \mathrm{mg} \mathrm{kg}^{-1}$ & 490 & 554 & 459 & 181 & 411 \\
\hline CN9 Total $\mathrm{P} \mathrm{mg} \mathrm{kg}^{-1}$ & 340 & 362 & 299 & 400 & 450 \\
\hline CS1 Plant available $\mathrm{P} \mathrm{mg} \mathrm{kg}{ }^{-1}$ & 3.2 & 3 & 4 & 1 & 3 \\
\hline CN9 Plant available $\mathrm{P} \mathrm{mg} \mathrm{kg}^{-1}$ & 6.2 & 3 & 1 & 2 & 2.8 \\
\hline $\mathrm{CS} 1$ inorganic $\mathrm{N} \mathrm{mg} \mathrm{kg}-1$ & 16.3 & 12.0 & 20.4 & 7.7 & 26.0 \\
\hline $\mathrm{CN} 9$ inorganic $\mathrm{N} \mathrm{mg} \mathrm{kg}{ }^{-1}$ & 13.5 & 16.4 & 5.6 & 16.5 & $\mathrm{n} / \mathrm{a}$ \\
\hline $\mathrm{CS} 1 \mathrm{pH}$ & 5.0 & 5.1 & 4.9 & 4.6 & 5.8 \\
\hline $\mathrm{CN} 9 \mathrm{pH}$ & 5.5 & 4.8 & 5.1 & 4.7 & 5.8 \\
\hline $\mathrm{CS} 1$ organic matter $(\% \mathrm{LOI})$ & 7.1 & 11.8 & 9.4 & 4.5 & nd \\
\hline $\mathrm{CN} 9$ organic matter (\% LOI) & 4.6 & 8.2 & 2.7 & 6.6 & nd \\
\hline
\end{tabular}

CN9 is the deforested catchment and CS1 the forested catchment 
would be expected (Table 1). Organic matter averaged $8.2 \%$ by weight (ranging between 4.5 and $11.8 \%$ ) in the forested catchment and $5.5 \%$ (ranging between 2.7 and $8.2 \%$ ) in the deforested catchment where there was less input of organic matter and more leaching and erosion due to the loss of forest litter. Inorganic $\mathrm{N}$ in soil samples ranged between 7 and $26 \mathrm{mg} \mathrm{kg}^{-1}$ and showed little difference between catchments (Table 1). Nutrient storage is an important aspect of soil organic matter where it has been found that $98 \%$ of total $\mathrm{N}$ and $65 \%$ of total $\mathrm{P}$ are stored (Van der Peijl and Verhoeven 2000; Werner 1984). The rate of decomposition is mediated by microorganisms in soil (Cleveland et al. 2003), soil pH and by soil temperatures (Sierra 2002; Grisi et al. 1998). Pastures are likely to have a reduction in overall microbial biomass (slowing decomposition) and higher soil temperatures (speeding decomposition) due to the lack of canopy shade (Cleveland et al. 2003). The net effect of the loss of input from forest litter and the changes in decomposition rates in deforested areas is the depletion of soil organic matter over time. This loss of soil organic matter implies release of $\mathrm{N}$ and $\mathrm{P}$ that is covalently bonded directly to carbon in soil organic matter. Loss then of organic matter is really a loss of available nutrients.

\section{Hydrological data}

The total rainfall for the study period of 1st June 2008 to 31st May 2009 was approximately 5,000 mm. Maximum rainfall during the wet season occurred on October 15th 2008 with a total of $300 \mathrm{~mm}$ of rain recorded. Heavy sustained rain was common in the wet season with several days of over $100 \mathrm{~mm}$ of rainfall. The dry season was very pronounced, with no rainfall at all from February 2nd to March 20th 2009 (Fig. 2). Though this amount of time without rainfall is unusual in the area, the annual rainfall of $5,000 \mathrm{~mm}$ is average for the Osa Peninsula. Rainfall was more common at night, with approximately twice as much rain recorded in the 6:00 rain gauge reading as compared to the 18:00 rain gauge reading.

Average normalized discharge in each stream was approximately $9 \mathrm{~mm}$ day $^{-1}\left(3,280 \mathrm{~mm} \mathrm{year}^{-1}\right)$ and the average evapotranspiration (ET) rate for a tropical lowland climate is $1,500 \mathrm{~mm} \mathrm{year}^{-1}$ (Aerts 1997; Penman 1948). The sum of local discharge and regional ET is very close to the annual rainfall during the study period of $5,000 \mathrm{~mm}$ and gives some degree of confidence to the discharge estimates. Flow duration probability tables show the percentage of time that discharges were equaled or exceeded and the periodic nature of high flows (Table 2). A comparison of the absolute discharge of the two streams showed that the forested catchment had approximately twice the average annual discharge of deforested catchment which was expected when the size of the catchments was compared. Normalized discharge, however, was approximately similar at approximately $9 \mathrm{~mm} \mathrm{day}^{-1}$ averaged over the period (Fig. 2). The major difference was in the wet and dry seasons, where in the wet season the deforested catchment had approximately twice the discharge per unit area and during the dry season the catchment had only a small fraction of the discharge per unit area.

The discharge frequency percentile Q5:Q95 ratios compare the magnitude of the infrequent 5 th \%o (Q5) highflow discharges to the frequent 95th \%o (Q95) low-flow discharges of the mean daily flow. Higher ratios correspond to flashier (shorter duration, higher magnitude runoff) systems due to faster flow paths most likely attributed to higher overland or near surface flow (Jordan et al. 2005; Jordan et al. (2012). The deforested catchment showed a much higher ratio (500:1) compared to the forested catchment (3.7:1) (Table 3). When only wet season discharge was considered, the Q5:Q95 ratio for the deforested catchment was reduced to 197:1 while the forested catchment remained almost unchanged at 3.4:1. Not only was the deforested catchment flashier, but also the maximum discharge was almost as high despite the catchment being approximately half the size.

Turbidity was also higher in the deforested catchment, where the highest turbidity recorded during storm flow was 241 NTU compared with 185 NTU for the forested catchment. Grab sample turbidity depended upon weather conditions at the time the sample was collected, and since grab samples could not be collected at the same time they do not correlate well during the wet season. Dry season average turbidity was 3.7 times higher in the deforested catchment. The high Q5:Q95 ratio and higher turbidity values suggest a larger erosive potential in the deforested catchment, likely leading to an increased sediment load and a greater loss of the particulate $\mathrm{P}$ fraction (e.g., Jordan et al. 2005; Douglas et al. 2007).

\section{Nitrogen in stream water}

Dissolved inorganic nitrogen (DIN) in stream water consists primarily of $\mathrm{NH}_{4}{ }^{+}$and/or $\mathrm{NO}_{3}{ }^{-}$(with $\mathrm{NO}_{2}{ }^{-}$typically found in waters with a wastewater or anaerobic source) (Lewis et al. 1999). Nitrate was below detection limits in all Sorbicell cartridges, which was surprising as $\mathrm{N}$ compounds are typically found in higher concentrations in fresh waters than P compounds. Hach DR890 colorimetric analysis was used as an alternative method to detect $\mathrm{NO}_{3}{ }^{-}$and $\mathrm{NH}_{4}{ }^{+}$in grab samples but concentrations were also very low and just above detection limits $\left(0.01 \mathrm{mg} \mathrm{L}^{-1}\right)$ for this method. When the concentration was below the detection limit and the reading was $0.00 \mathrm{mg} \mathrm{L}^{-1}$, this value was used when taking averages of $\mathrm{N}$ concentrations in stream water. 
Fig. 2 Rainfall (light dashed line) and discharge (dark line) for the forested catchment (a) and the deforested catchment (b) for the study period of June 2008 through June 2009 show a pronounced dry season in February-March with several weeks without any rainfall
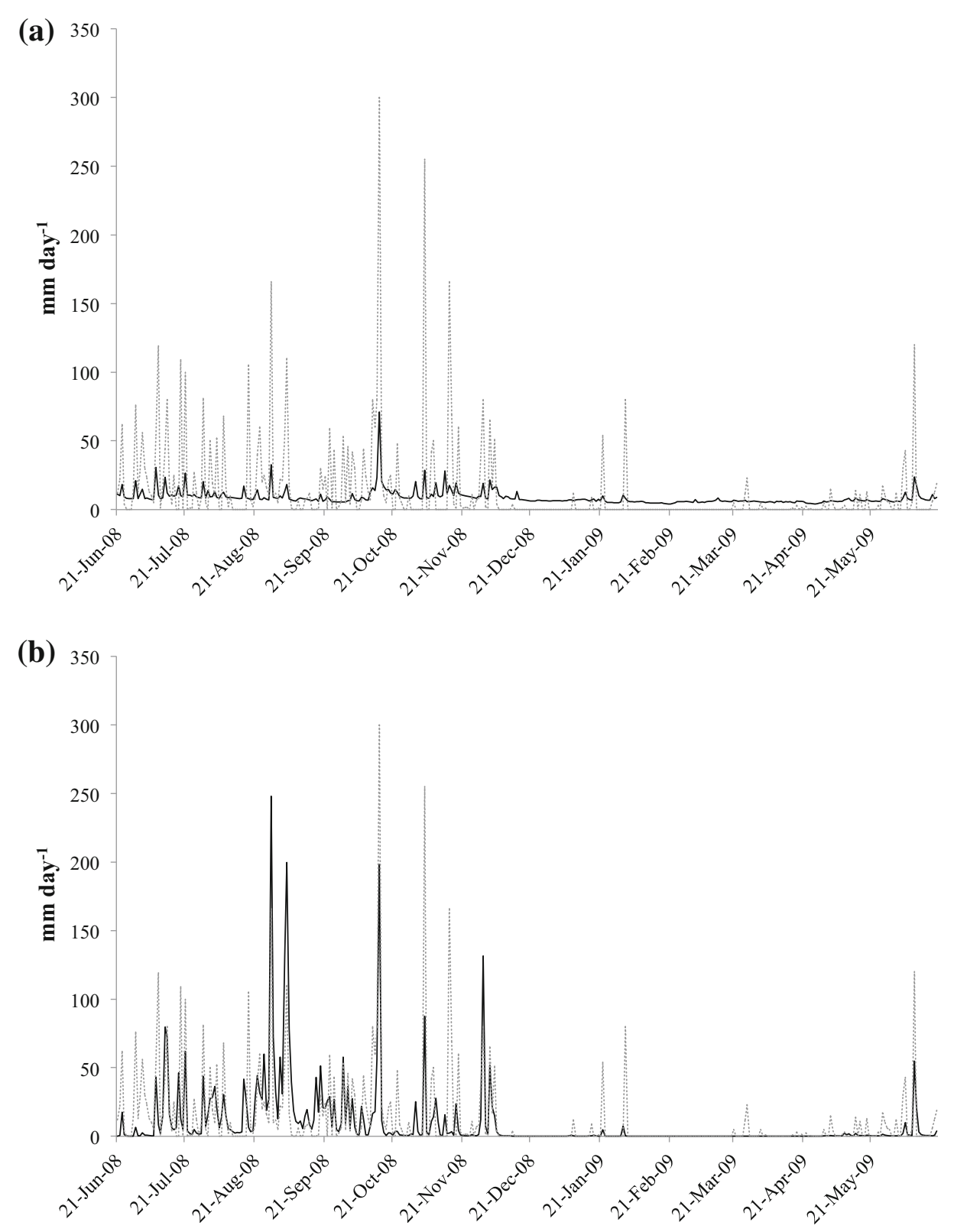

Studies at the La Selva Biological Station (North Atlantic slope of Costa Rica) and in northwestern Costa Rica showed stream $\mathrm{NO}_{3}{ }^{-}$concentrations an order of magnitude higher (0.12-0.30 $\mathrm{mg} \mathrm{L}^{-1}$ ) (Stallcup et al. 2006; Pringle and Triska 1991; Newbold et al. 1995; Neill et al. 2001). Discharge distributions of grab samples (G) and stormwater samples (SW) are listed as the number of samples collected between the listed discharge and the next highest (Table 2). Low nitrogen concentrations have also been found in other small streams in the Osa Peninsula ( $P$. Taylor, personal communication).

Paired-samples t tests were conducted to compare the effect of deforestation and seasonal variations in climate on nutrient concentrations. The deforested catchment stream had higher concentrations of DIN (Fig. 3) with the exception of storm flows, where the mean DIN concentrations were significantly higher $(\rho<0.05)$ in the forested catchment $\left(0.044 \mathrm{mg} \mathrm{L}^{-1}\right)$ compared to the deforested catchment $\left(0.023 \mathrm{mg} \mathrm{L}^{-1}\right)$. Average annual DIN concentrations show a significantly higher $(\rho<0.05)$ concentration of DIN in the stream draining the deforested catchment (0.035 $\mathrm{mg} \mathrm{L} \mathrm{L}^{-1}$ ) compared to the forested catchment $\left(0.028 \mathrm{mg} \mathrm{L}^{-1}\right)$. During the wet season the concentration of DIN in the deforested catchment stream $\left(0.043 \mathrm{mg} \mathrm{L}^{-1}\right)$ was 1.5 times higher $(\rho<0.05)$ than the forested catchment $\left(0.029 \mathrm{mg} \mathrm{L}^{-1}\right)$. Likewise, the dry season DIN concentrations were significantly higher $(\rho<0.05)$ by a factor of 1.6 in the stream draining the deforested catchment 
Table 2 A comparison of the probability that discharge will exceed the indicated discharge for listed percentiles for the forested catchment (CS1) and the deforested catchment (CN9)

\begin{tabular}{|c|c|c|c|c|c|}
\hline Depth $\mathrm{cm}$ & Discharge $\mathrm{m}^{3} \mathrm{~s}^{-1}$ & Discharge $\mathrm{mm} \mathrm{s}^{-1}$ & Discharge mm day ${ }^{-1}$ & \# samples and type & Probability \% \\
\hline \multicolumn{6}{|c|}{ CS1 flow duration probability and sample collection discharge distribution } \\
\hline 63.9 & 1.532 & $3.83 \times 10^{-3}$ & 71.0 & & Highest flow \\
\hline 16.9 & 0.066 & $1.66 \times 10^{-4}$ & 18.4 & $2 \mathrm{G}, 8 \mathrm{SW}$ & 5 \\
\hline 14.9 & 0.051 & $1.27 \times 10^{-4}$ & 13.2 & $1 \mathrm{G}$ & 10 \\
\hline 13.6 & 0.042 & $1.06 \times 10^{-4}$ & 9.98 & $1 \mathrm{G}, 1 \mathrm{SW}$ & 20 \\
\hline 12.9 & 0.039 & $9.64 \times 10^{-5}$ & 8.75 & $1 \mathrm{G}$ & 30 \\
\hline 12.2 & 0.035 & $8.84 \times 10^{-5}$ & 8.03 & $6 \mathrm{G}$ & 40 \\
\hline 11.5 & 0.032 & $8.05 \times 10^{-5}$ & 7.24 & $6 \mathrm{G}$ & 50 \\
\hline 11.1 & 0.030 & $7.52 \times 10^{-5}$ & 6.59 & $3 \mathrm{G}$ & 60 \\
\hline 10.6 & 0.028 & $7.11 \times 10^{-5}$ & 6.22 & $3 \mathrm{G}$ & 70 \\
\hline 10.1 & 0.027 & $6.65 \times 10^{-5}$ & 5.86 & $6 \mathrm{G}$ & 80 \\
\hline 9.5 & 0.025 & $6.13 \times 10^{-5}$ & 5.40 & $10 \mathrm{G}$ & 90 \\
\hline 8.9 & 0.023 & $5.65 \times 10^{-5}$ & 4.94 & $4 \mathrm{G}$ & 95 \\
\hline 6.5 & 0.016 & $4.03 \times 10^{-5}$ & 4.08 & $7 \mathrm{G}$ & Lowest flow \\
\hline \multicolumn{6}{|c|}{ CN9 flow duration probability and sample collection discharge distribution } \\
\hline 44.5 & 1.305 & $6.52 \times 10^{-3}$ & 248.0 & & Highest flow \\
\hline 17.7 & 0.106 & $5.31 \times 10^{-4}$ & 46.3 & $10 \mathrm{SW}$ & 5 \\
\hline 15.4 & $4.09 \times 10^{-2}$ & $2.05 \times 10^{-4}$ & 27.4 & $2 \mathrm{G}$ & 10 \\
\hline 13.0 & $1.26 \times 10^{-2}$ & $6.28 \times 10^{-5}$ & 11.1 & $5 \mathrm{G}$ & 20 \\
\hline 11.1 & $4.64 \times 10^{-3}$ & $2.32 \times 10^{-5}$ & 3.59 & $3 \mathrm{G}$ & 30 \\
\hline 9.2 & $1.81 \times 10^{-3}$ & $9.07 \times 10^{-6}$ & 1.23 & & 40 \\
\hline 8.2 & $1.07 \times 10^{-3}$ & $5.37 \times 10^{-6}$ & 0.518 & $2 \mathrm{G}$ & 50 \\
\hline 7.3 & $6.96 \times 10^{-4}$ & $3.48 \times 10^{-6}$ & 0.343 & $7 \mathrm{G}$ & 60 \\
\hline 6.1 & $3.77 \times 10^{-4}$ & $1.88 \times 10^{-6}$ & 0.161 & $9 \mathrm{G}$ & 70 \\
\hline 5.5 & $2.78 \times 10^{-4}$ & $1.39 \times 10^{-6}$ & 0.121 & $6 \mathrm{G}$ & 80 \\
\hline 5.1 & $2.23 \times 10^{-4}$ & $1.12 \times 10^{-6}$ & 0.099 & $7 \mathrm{G}$ & 90 \\
\hline 4.8 & $1.92 \times 10^{-4}$ & $9.62 \times 10^{-7}$ & 0.090 & $3 \mathrm{G}$ & 95 \\
\hline 3.4 & $9.69 \times 10^{-5}$ & $4.84 \times 10^{-7}$ & 0.0036 & $2 \mathrm{G}$ & Lowest flow \\
\hline
\end{tabular}

Distribution of grab samples $(\mathrm{G})$ and stormwater samples $(\mathrm{SW})$ is listed as the number of samples collected between the listed discharge and the next highest

Table 3 A comparison of the discharge and high percentile to low percentile (Q5:Q95) of the two streams

\begin{tabular}{llllllll}
\hline & $\begin{array}{l}\text { Annual } \\
\text { discharge } \\
\text { mm day }^{-1}\end{array}$ & $\begin{array}{l}\text { Wet season } \\
\text { discharge } \\
\text { mm day }^{-1}\end{array}$ & $\begin{array}{l}\text { Dry season } \\
\text { discharge } \\
\text { mm day }\end{array}$ & Q5:Q95 & $\begin{array}{l}\text { Max. discharge m } \\
\mathrm{s}^{-1}\left(\mathrm{~mm} \mathrm{~s}^{-1}\right)\end{array}$ & $\begin{array}{l}\text { Min. discharge } \mathrm{m}^{3} \mathrm{~s}^{-1} \\
\left(\mathrm{~mm} \mathrm{~s}^{-1}\right)\end{array}$ & $\begin{array}{l}\text { Q5:Q95 ratio } \\
\mathrm{June}^{-D e c}\end{array}$ \\
\hline CN9 & 9.55 & 18.58 & 0.23 & 500 & $1.3\left(6.5 \times 10^{-3}\right)$ & $9.69 \times 10^{-5}\left(8.5 \times 10^{-7}\right)$ & 197 \\
CS1 & 8.92 & 11.06 & 5.98 & 3.7 & $1.53\left(3.8 \times 10^{-3}\right)$ & $1.6 \times 10^{-2}\left(4.3 \times 10^{-5}\right)$ & 3.4 \\
\hline
\end{tabular}

CN9 is the deforested catchment and CS1 the forested catchment

(0.032 $\left.\mathrm{mg} \mathrm{L}^{-1}\right)$ compared to the forested catchment $\left(0.020 \mathrm{mg} \mathrm{L}^{-1}\right)$. These changes were close to the $1.8 \mathrm{av-}$ erage increases found in deforested streams in the Amazon basin (Williams and Melack 1997).

Higher concentrations of DIN in stream water from the deforested catchment are mostly due to significantly higher $(\rho<0.05)$ concentrations of ammonium $\left(\mathrm{NH}_{4}{ }^{+}-\mathrm{N}\right)$. Ammonium concentrations were found to be twice as concentrated in deforested catchment during the wet season (deforested catchment $=0.022 \mathrm{mg} \mathrm{L}^{-1}$, forested catchment $\left.=0.011 \mathrm{mg} \mathrm{L}^{-1}\right)$ and three times as concentrated during the dry season (deforested catchment $=0.017 \mathrm{mg} \mathrm{L}^{-1}$, forested catchment $=0.006 \mathrm{mg} \mathrm{L}^{-1}$ ). Only during storm, flow was the average concentration of $\mathrm{NH}_{4}{ }^{+}$higher in the forested catchment. Nitrate $\left(\mathrm{NO}_{3}{ }^{-}-\mathrm{N}\right)$ average concentrations by comparison were almost identical $\left(0.017-0.018 \mathrm{mg} \mathrm{L}^{-1}\right)$ in 


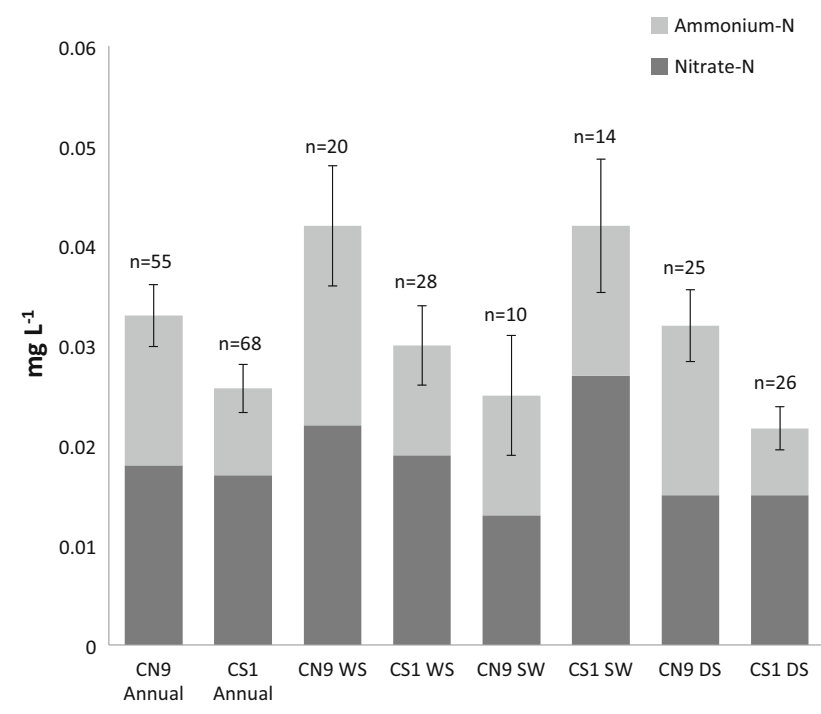

Fig. 3 A comparison of annual, wet season (WS), stormwater (SW) and dry season (DS) DIN $\left(\mathrm{NO}_{3}{ }^{-}+\mathrm{NH}_{4}{ }^{+}\right)$concentrations $\left(\mathrm{mg} \mathrm{L}^{-1}\right)$ between the deforested catchment (CN9) and the forested catchment (CS1). Error bars indicate standard errors of the mean for DIN

the two streams (Fig. 3). Stormwater samples taken during flood events had a significantly lower $(\rho<0.05)$ concentration of $\mathrm{NO}_{3}{ }^{-} \mathrm{N}$ in the deforested catchment $(0.011 \mathrm{mg}$ $\mathrm{L}^{-1}$ ) compared to the forested catchment where the concentrations were 2.5 times greater $\left(0.028 \mathrm{mg} \mathrm{L}^{-1}\right)$. When average wet season $\mathrm{NO}_{3}{ }^{-}-\mathrm{N}$ concentrations are compared with stormwater $\mathrm{NO}_{3}{ }^{-}-\mathrm{N}$ concentrations for each catchment there is a decline in concentrations in the deforested catchment and an increase in concentrations in the forested catchment. It appears that the difference in $\mathrm{NO}_{3}{ }^{-}-\mathrm{N}$ concentrations in the deforested stream $\mathrm{NO}_{3}{ }^{-}-\mathrm{N}$ (wet season $=$ $0.022 \mathrm{mg} \mathrm{L}^{-1}$; stormwater flow $=0.011 \mathrm{mg} \mathrm{L}^{-1}$ ) was due to higher discharge causing a $50 \%$ dilution of $\mathrm{NO}_{3}{ }^{-}-\mathrm{N}$ during storm flow. This apparent dilution, however, still represents an increase in load (discharge $\mathrm{x}$ concentration) with storm flows, albeit with a lower rate of concentration change, compared with discharge. In the forested stream, the amount of $\mathrm{NO}_{3}{ }^{-}-\mathrm{N}$ was $54 \%$ higher (wet season $=0.0180 \mathrm{mg} \mathrm{L}^{-1}$; stormwater flow $\left.=0.028 \mathrm{mg} \mathrm{L}^{-1}\right)$. Decomposition of leaf litter in the forested catchment along with the lack of forest litter and faster runoff in the deforested catchment was the probable cause of these significant differences in concentrations of $\mathrm{NH}_{4}^{+}-\mathrm{N}$ and $\mathrm{NO}_{3}^{-}-\mathrm{N}$ in stormwater flows.

\section{Phosphorus in stream water}

Soluble reactive $\mathrm{P}$ concentrations in stream grab and storm samples ranged from 0.03 to $0.33 \mathrm{mg} \mathrm{L}^{-1}$ while time- and flow-integrated Sorbicell cartridges' concentrations ranged from 0.006 to $0.050 \mathrm{mg} \mathrm{L}^{-1}$. For comparison, other studies showed stream SRP concentrations at the La Selva Biological

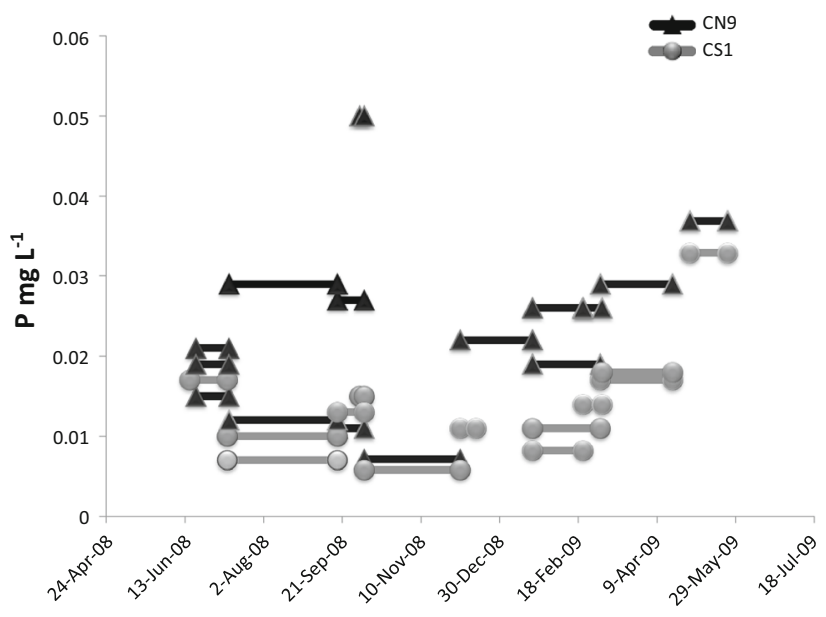

Fig. 4 SRP concentrations $\left(\mathrm{mg} \mathrm{L}^{-1}\right)$ as measured by Sorbicell cartridges deployed in streams, dark lines with triangles for the deforested catchment (CN9) and light lines with circles for the forested catchment (CS1)

Station (North Atlantic slope of Costa Rica) of 0.002-0.040 $\mathrm{mg} \mathrm{L}^{-1}$ (Stallcup et al. 2006; Pringle and Triska 1991) and 0.008-0.029 $\mathrm{mg} \mathrm{L}^{-1}$ in streams in northwestern Costa Rica (Newbold et al. 1995) and reflect low-flow grab sample concentrations and time-integrated trends. Sorbicell cartridges were deployed for a period of a few days to 5 weeks and continually collected P in flowing water. Reactive phosphorus concentrations measured by Sorbicell cartridges showed almost without exception that the concentrations were higher by a factor of 2 in the deforested catchment than in the forested catchment (Fig. 4). A pairedsamples $t$ test was conducted to compare the SRP concentrations in the two streams and showed there was a significant difference $(\rho<0.05)$ in the mean concentration of SRP in the stream draining the deforested catchment $\left(0.024 \mathrm{mg} \mathrm{L}^{-1}\right)$ compared to the forested catchment $\left(0.014 \mathrm{mg} \mathrm{L}^{-1}\right)$ during the study period. While the Sorbicell cartridges showed lower concentrations than the grab sample method, the seasonal variation of SRP transfer is more accurately portrayed by continuous flow-proportional monitoring than in occasional grab sample analysis (Rozemeijer et al. 2010).

\section{Nutrient load}

Potential impacts resulting from the significant increase in the concentration of both DIN and SRP in stream waters draining the deforested catchment can affect both freshwater and marine systems. Annual mass transfer $\left(\mathrm{kg} \mathrm{km}^{-2}\right.$ year $\left.^{-1}\right)$ for each of the nutrients was calculated to compare nutrient load to other studies and to quantify the potential impact of observed nutrient concentrations. The annual load of nutrients was calculated using a method modified from Johnes (2007) that suited the sampling 
protocol and took into account the differences in catchment size (Eq. 2).

Load $=\sum_{i=1}^{n} \frac{\left(C_{i} Q_{p i} t\right)}{A}$,

where $C i$ is the nutrient concentration of the deployment (mg L ${ }^{-1}$ or $\mathrm{g} \mathrm{m}^{-3}$ ), $Q_{p i}$ the average discharge during the deployment $\left(\mathrm{m}^{3}\right), t$ the deployment duration and $A$ the catchment area $\left(\mathrm{km}^{2}\right)$.

The deployment period of the Sorbicell cartridges was used as the time $(t)$ for both the $\mathrm{P}$ and $\mathrm{N}$ loads. Soluble reactive $\mathrm{P}$ measured using Sorbicell cartridges showed the deforested catchment transferred $60 \mathrm{~kg} \mathrm{P} \mathrm{km}^{-2}$ year $^{-1}$ and the forested catchment $42 \mathrm{~kg} \mathrm{P} \mathrm{km}^{-2}$ year $^{-1}$. The mass transfer of DIN was calculated using the average concentrations of DIN in grab and stormwater samples during the deployment period $(t)$ resulting in losses from the deforested catchment of $113\left(\mathrm{~kg} \mathrm{~N} \mathrm{~km}^{-2}\right.$ year $\left.{ }^{-1}\right)$, while the forested catchment lost $58\left(\mathrm{~kg} \mathrm{~N} \mathrm{~km}^{-2}\right.$ year $\left.^{-1}\right)$.

\section{Molar nitrogen: phosphorus ratios and nutrient limitation}

Molar ratios of $\mathrm{N}: \mathrm{P}$ were determined as the quotient of molar DIN $\left(\mathrm{NO}_{3}{ }^{-}+\mathrm{NH}_{4}{ }^{+}\right)$by the molar SRP. Mean N:P values for deforested and forested catchments, respectively, were 0.91 and 0.76 (grab sample data) and were small compared to the Redfield ratio of 16:1 (Downing et al. 1999) and studies in La Selva, Costa Rica (Redfield ratio = 16.4:1 to 198:1) (Stallcup et al. 2006) and northwestern Costa Rica (Redfield ratio $=20: 1$ to $45: 1$ ) (Newbold et al. 1995). Nutrient uptake kinetics have demonstrated that $\mathrm{N}: \mathrm{P}$ ratios $<10$ indicate $\mathrm{N}$ limitation in a system (Kress et al. 2002), though experimental studies involving nutrient additions are the established methods to determine if a particular nutrient limits production (Vitousek and Howarth 1991). The surprisingly low $\mathrm{N}$ concentrations for both streams and the low N:P mole ratio suggest that the streams are N-limited. Traditional thought is that $\mathrm{P}$ is limiting in mature tropical rainforests (Vitousek et al. 2010). This is unlikely on the Osa Peninsula where rapid uplift of the region exposes unweathered volcanic rock. Chemical weathering of these volcanic rocks contribute to the relatively high $\mathrm{P}$ concentrations in the soils.

\section{Potential impacts of deforestation}

Terrestrial impacts of deforestation are easily seen, yet changes to nutrient cycles in streams can have profound impacts on stream and coastal aquatic ecosystems. Models suggest when $\mathrm{N}$ loading is coupled with higher $\mathrm{P}$ loads that tropical eutrophication will result in ecosystem-level impacts that are more severe in the tropics than in temperate climates (Downing et al. 1999). Tropical marine systems vary from P-limited mangroves and reefs to N-limited coastal zones and light-limited deltaic zones. Tropical freshwaters are more frequently $\mathrm{N}$-limited while tropical marine systems tend to be P-limited (Vitousek and Howarth 1991). These systems will likely be affected by disruption of tropical terrestrial ecosystems, which is likely to lead to greater $\mathrm{N}$ loss and increased primary production in tropical freshwater streams leading to changes in freshwater communities. River deltas may see higher production leading to light-limited zones while calcareous marine systems may see a switch from $\mathrm{P}$ to $\mathrm{N}$ limitation (Downing et al. 1999). In particular, coral reefs suffer when nutrient concentrations and/or turbidity increase (Richmond 1993). Studies such as this are important because changes to aquatic ecosystems frequently go undetected until the problem is too large to be easily reversed.

Forest restoration can often reverse the trends in soil and water degradation although complete recovery may never fully be realized (e.g., Harris and Heathwaite 2011). Studies of deforested tropical areas of Australia show that reforestation projects cause nitrification, soil bulk densities, $\mathrm{pH}$ and $\mathrm{PO}_{4}^{3-}$ concentrations to be successfully reestablished to pre-disturbance concentrations (Paul et al. 2010). Secondary forests tend to have a rapid accumulation of nutrients in vegetation and return of nutrients by litterfall, followed by rapid decomposition and uptake of nutrients by roots. The rate of return of organic $\mathrm{P}$ to soils is faster during first 20 years of secondary forest development, after which the rate more closely matches that of a mature forest (Brown and Lugo 1990). Changes to nutrient cycles and hydrological discharge in deforested areas are just one of the issues to be considered when land-use planning decisions are made.

\section{Conclusions}

Deforestation impacted soils in the Osa Peninsula study area by altering $\mathrm{P}$ and $\mathrm{N}$ concentrations and loads and turbidity in receiving waters. The $33 \%$ reduction in soil organic matter in the deforested catchment has impacted nutrient cycles, decreasing the stored nutrient capacity and increasing the rate of loss of both $\mathrm{N}$ and $\mathrm{P}$. Concentrations for both total and soil-available $\mathrm{P}$ were higher in the forested catchment with reductions in total and soil-available $\mathrm{P}$ likely due to greater leaching in the deforested catchment.

Rainfall and stream stage data were used to assess the hydrological changes caused by deforestation by measuring the input and output budgets for water. The effect of deforestation on stream discharge was a $59 \%$ higher flow 
during the wet season and an increase in the Q5:Q95 ratio showing that the deforested stream was flashier. Dry season had a dramatic $96 \%$ reduction in stream flow in the deforested catchment resulting from greater solar radiation and corresponding increased rates of soil moisture evaporation due to a removed canopy (Ghuman 1987).

Nitrogen concentrations in both streams were surprisingly low, which has also been found in other small streams in the Osa Peninsula. Molar N:P ratios were low and were all well below the Redfield ratio of 16:1. Concentrations of DIN for both streams were near $0.03 \mathrm{mg} \mathrm{L}^{-1}$ well below the $0.06 \mathrm{mg}$ $\mathrm{L}^{-1}$ level at which $\mathrm{N}$ limitation of lotic algal growth has been reported (Newbold 1992), and also indicate that $\mathrm{N}$ is the limiting nutrient in streams in the study area.

The deforested catchment estimated load of DIN was $95 \%$ higher resulting in an extra $55 \mathrm{~kg} \mathrm{~N} \mathrm{~km}^{-2}$ year $^{-1}$ exported to coastal waters due to deforestation. The export of SRP was $43 \%$ higher in the deforested catchment resulting in an additional $18 \mathrm{~kg} \mathrm{P} \mathrm{km}^{-2}$ year $^{-1}$ exported to coastal waters due to deforestation and soil nutrient depletion. Effects of nutrient loading have been observed through increased algal growth on equipment surfaces in deforested catchment stream. Higher turbidity values in the deforested catchment stream suggest a larger erosive potential with an increased sediment load. Higher suspended sediment loads will likely lead to light limitation and reef sedimentation which will diminish the photosynthetic range of corals and result in the decline in live coral cover and species diversity.

The study suggests that the tropical forest to pastureconverted catchment is still in a period of establishing a new equilibrium between nutrient source and transfer processes. Although the impacted study catchment represents a small area in this part of the Costa Rican Pacific coast, the results are indicative of a wider environmental impact to a series of mature tropical ecosystems from catchment to coast should deforestation in this region go unmanaged.

Acknowledgments We thank the people at the Campanario Biological Reserve on the Osa Peninsula, Costa Rica for access to the forest and stream on their private reserve. With particular appreciation to Arnulfo Montes Torres for his help in maintaining equipment while away from the field station and Leslie at the office for making necessary accommodations. Donna Dillingham-Evans and Vic Hasfurther from Dixie State College provided assistance in the form of a sabbatical and funding and Vic Hasfurther provided hydrometric advice. Chad Bringhurst provided statistical advice. We would also like to thank Phil Taylor (University of Colorado, Boulder) for his feedback and information about $\mathrm{N}$ cycling and other studies in the area.

\section{References}

Aerts R (1997) Climate, leaf litter chemistry and leaf litter decomposition in terrestrial ecosystems: a triangular relationship. Oikos 79(3):439-449
Arnscheidt J, Jordan P, Li S, McCormick S, McFaul R, McGrogan H et al (2007) Defining the sources of low-flow P transfers in complex catchments. Sci Total Environ 382:1-13

Bern C, Townsend A, Farmer G (2005) Unexpected dominance of parent-material strontium in a tropical forest on highly weathered soils. Ecology 86(3):626-632

Biggs T, Dunne T, Martinelli L (2004) Natural controls and human impacts on stream nutrient concentrations in a deforested region of the Brazilian Amazon Basin. Biogeochemistry 68(2):227-257

Borbor-Cordova M, Boyer E, McDowell W, Hall C (2006) Nitrogen and $\mathrm{P}$ budgets for a tropical watershed impacted by agricultural land use: Guayas, Ecuador. Biogeochemistry 79:135-161

Bray R, Kurtz L (1945) Determination of total, organic and available forms of P in soils. Soil Sci 59:39-45

Brown S, Lugo A (1990) Tropical secondary forests. J Trop Ecol 6(1): $1-32$

Caiado MA (2005) Modeling fate and transport of nitrogen and phosphorus in crop fields under tropical conditions. Virginia Polytechnic Institute and State University, Biological Systems Engineering. Blacksburg, Virginia: Virginia Polytechnic Institute and State University

Carter R, Davidian J (1989) Chapter A6: general procedure for gaging streams. In: Carter R, Davidian J (ed) Techniques of waterresources investigations of the U.S. Geological Survey, Book 3. Washington, D.C., USA: USGS

Cleveland C, Townsend A (2006) Nitrogen and phosphorus additions cause substantial losses of soil carbon from a lowland tropical rainforest. Proc Natl Acad Sci 103(10):316-321

Cleveland C, Townsend A, Schmidt S, Constance B (2003) Soil microbial dynamics and biogeochemistry in tropical forests and pastures, Southwestern Costa Rica. Ecol Appl 13(2):314-326

Cleveland C, Townsend A, Constance B, Ley R, Schmidt S (2004) Soil microbial dynamics in Costa Rica: seasonal and biogeochemical constraints. Biotropica 36(2):184-195

De Jonge H, Rothenberg G (2005) New device and method for fluxproportional sampling of mobile solutes in soil and groundwater. Environ Sci Technol 39:274-282

Douglas R, Menary W, Jordan P (2007) Phosphorus and sediment transfers in a grassland river catchment. Nutr Cycl Agroecosyst $77: 199-212$

Downing J, McClain M, Twilley R, Melack J, Elser JNR et al (1999) The impact of accelerating land-use change on the N-cycle of tropical aquatic ecosystems: current conditions and projected changes. Biogeochemistry 46(1):109-148

Gardner T, Verdonck D, Pinter N, Slingerland R, Furlong K, Bullard T et al (1992) Quaternary uplift astride the aseismic Cocos Ridge, Pacific coast, Costa Rica. Geol Soc Am Bull 104:219-232

Ghuman B (1987) Effects of partial clearing on microclimate in a humid tropical forest. Agric Forest Meteorol 40(1):17

Grisi B, Grace C, Brookes P, Benedetti A, Dell'Abate M (1998) Temperature effects on organic matter and microbial biomass dynamics in temperate and tropical soils. Soil Biol Biochem 30(10):1309-1315

Harmel R, King K, Haggard B, Wren D, Sheridan J (2006) Practical guidance for discharge and water quality data collection on small watersheds. Trans ASABE 49(4):937-948

Harris GP, Heathwaite AL (2011) Why is achieving good ecological outcomes in rivers so difficult? Freshw Biol. doi:10.1111/j.13652427.2011.02640.x

Hartshorn G (1983) Plants: introduction. In: Janzen D (ed) Costa rican natural history. University of Chicago Press, Chicago, pp 118-183

Johnes PJ (2007) Uncertainties in annual riverine phosphorus load estimation: impact of load estimation methodology, sampling frequency, baseflow index and catchment population density. J Hydrol 332:241-258 
Jordan C, Herrera R (1981) Tropical rain forests: are nutrients really critical? Am Nat 117(2):167-180

Jordan P, Menary W, Daly K, Kiely G, Morgan G, Byrne P et al (2005) Patterns and processes of phosphorus transfer from Irish grassland soils to rivers-integration of laboratory and catchment studies. J Hydrol 304:20-34

Jordan P, Melland AR, Mellander PE, Shortle G, Wall D (2012) The seasonality of phosphorus transfers from land to water: implications for trophic impacts and policy evaluation. Sci Total Environ 434:101-109

Keeney D, Nelson D (1982) Nitrogen-inorganic forms. In: Page A (ed) Methods of soil analysis, part 2 Agron. Monogr, 2nd edn. ASA and SSSA, Madison, pp 643-698

Kress N, Coto S, Brenes C, Brenner S, Arroyo G (2002) Horizontal transport and seasonal distribution of nutrients, dissolved oxygen and chlorophyll-a in the Gulf of Nicoya, Costa Rica: a tropical estuary. Cont Shelf Res 22:51-66

Lewis W, Melack J, McDowell W, McClain M, Richey J (1999) Nitrogen yields from undisturbed watersheds in the Americas. Biogeochemistry 46(1/3):149-162

Lohse K, Brooks P, McIntosh J, Meixner T, Huxman T (2009) Interactions between biogeochemistry and hydrologic systems. Annu Rev Environ Resour 34:65-96

Neill C, Deegan L, Thomas S, Cerri C (2001) Deforestation for pasture alters nitrogen and phosphorus in small amazonian streams. Ecol Appl 11(6):1817-1828

Newbold J (1992) Cycles and spirals of nutrients. In: Calow P, Petts G (eds) The rivers handbook, vol 1., Hydrological and ecological principlesBlackwell Scientific, Oxford, pp 379-408

Newbold J, Sweeney B, Jackson J, Kaplan L (1995) Concentrations and export of solutes from six mountain streams in Northwestern Costa Rica. J North Am Benthol Soc 14(1):21-37

Paul M, Catterall C, Pollard P, Kanowski J (2010) Recovery of soil properties and functions in different rainforest restoration pathways. For Ecol Manage 259:2083-2092

Penman HL (1948) Natural evaporation from open water, bare soil and grass. In: Proceeding of the Royal Society of London. Series A, Mathematical and Physical Sciences 1948, vol 193, pp 120-145

Phillips J, Russell M, Walling D (2000) Time-integrated sampling of fluvial suspended sediment: a simple methodology for small catchments. Hydrol Process 14:2589-2602

Pierzynski G (2000) Methods of phosphorus analysis for soils. Residuals, and Waters. Southern Cooperative Series, Sediments

Pringle C, Triska F (1991) Effects of geothermal groundwater on nutrient dynamics of a Lowland Costa Rican Stream. Ecology 72(3):951-965

Richmond R (1993) Coral reefs: present problems and future concerns resulting from anthropogenic disturbance. Am Zool 33(6):524-536
Rozemeijer J, Van Der Velde Y, De Jonge H, Van Geer F, Broers H, Bierkens M (2010) Application and evaluation of a new passive sampler for measuring average solute concentrations in a catchment scale water quality monitoring study. Environ. Sci. Tech. 44(4):1353-1359

Sanchez-Azofeifa G, Rivard B, Calvo J, Moorthy I (2002) Dynamics of tropical deforestation around national parks: remote sensing of forest change on the Osa Peninsula of Costa Rica. Mt Res Dev 22(4):352-358

Sanchez-Azofeifa A, Daily GC, Pfaff AS, Busch C (2003) Integrity and isolation of Costa Rica's national parks and biological reserves: examining the dynamics of land-cover change. Biol Conserv 109:123-135

Sierra J (2002) Nitrogen mineralization and nitrification in a tropical soil: effects of fluctuating temperature conditions. Soil Biol Biochem 34:1219-1226

Spring D, Baum J, Mac NR, Mackenzie M, Sanchez-Azofeifa A, Thomson JR (2010) Building a regionally connected reserve network in a changing and uncertain World. Conserv Biol 24(3):691-700

Stallcup L, Ardon M, Pringle C (2006) Does nitrogen become limiting under high-P conditions in detritus-based tropical streams? Freshw Biol 51:1515-1526

Storer D (1984) A simple high sample volume ashing procedure for determining soil organic matter. Soil Sci. Plant Anal. 15:759-772

Van Der Peijl M, Verhoeven J (2000) Carbon, nitrogen and phosphorus cycling in river marginal wetlands: a model examination of landscape geochemical flows. Biogeochemistry 50(1):45-71

Vitousek P, Howarth R (1991) Nitrogen limitation on land and in the sea: how can it occur? Biogeochemistry 13(2):87-115

Vitousek PM, Porder S, Houlton BZ, Chadwick OA (2010) Terrestrial phosphorus limitation: mechanisms, implications, and nitrogenphosphorus interactions. Ecol Appl 20:5-15

Werner P (1984) Changes in soil properties during tropical wet forest succession in Costa Rica. Biotropica 16(1):43-50

Williams M (2008) A new look at global forest histories of land clearing. Annu Rev Environ Resour 33:345-367

Williams M, Melack J (1997) Solute export from forested and partially deforested catchments in the Central Amazon. Biogeochemistry 38(1):67-102

Yanez-Arancibia A, Lara-Dominquez A (1998) Mangrove ecosystems in Tropical America: structure, function, and management. University of Campeche. Campeche, Mexico: EPOMEX Scientific Series 3 